\title{
REFORM OF CORPORATE ACCOUNTING AND AUDITING IN MONTENEGRO IN THE PROCESS OF EU ACCESSION
}

\author{
Mijat Jocović* \\ Nikola Milović ${ }^{* *}$
}

\begin{abstract}
The aim of this paper is to analyze the quality of the legal solutions contained in the regulation of accounting and auditing in Montenegro. The research into the area has been carried out by taking into account the needs of harmonization of the Montenegrin legal system with that of the EU, but also in relation to the necessity of solving the many problems posed by the practice of implementation of the earlier legislation. Using primarily a comparative method, as well as a detailed analysis of the norms in this area in Montenegro, the authors put forward the conclusion that harmonization process in the area of accounting law should contribute to strengthening the competitiveness of the national economy and improving the legal security of holders of material interests. After analyzing the process of adoption and implementation of laws in the area of accounting and auditing, an additional conclusion has arisen - that in the process of adopting the Law on Accounting and the Law on Auditing, the legislator placed greater emphasis on formal alignment with EU law than on the need for laws to create prerequisites for further development of these areas in Montenegro.
\end{abstract}

\section{INTRODUCTION}

The sudden bankruptcies of large joint stock companies around the world at the end of last and the beginning of this century, which brought to the fore issues of accounting and auditing profession, placed this area on the list of reform priorities at the global level. The peak of the crisis, which also meant the start of regulatory reform, first in the United States of America (USA) and then in

\footnotetext{
Assistant Professor at Faculty of Economics, University of Montenegro; mijatj@ac.me

** Assistant Professor at Faculty of Economics, University of Montenegro; nmilovic@ac.me
} 
the European Union (EU), was the bankruptcy of Enron. ${ }^{1}$ The circumstances under which the bankruptcy of this company occurred and great media attention accompanied by the huge public pressure that ensued changed the way of thinking and action-taking of policy makers in developed countries. Energetic action did not follow only in the United States, where the bankruptcy of Enron occurred, however. These issues found their place among the top priorities of the reform of company law and corporate governance in the EU as well.

Realizing that company law and corporate governance within the EU did not follow the changes on a global scale caused by financial scandals, the European Commission launched a debate in which it instructed a group of experts to analyze the basic flaws in the European system of corporate governance and to propose guidelines for their improvement. The result of work of this group is a report entitled Report of the High Level Group of Company Law Experts on a Modern Regulatory Framework for Company Law in Europe. In this document, the reform of the system of financial reporting and auditing is foreseen as an important prerequisite for the improvement of corporate governance at the EU level. ${ }^{2}$

Within the EU, the issues of accounting and auditing are an integral part of European company law. In contrast to the concept of the USA, where in particular the aspects of financial reporting are largely regulated under the law of securities, in European law these are connected to the substance of company law. One of the reasons for such an approach is given in the preamble to the Directive on the annual financial statements, consolidated financial statements and related reports of certain types of undertakings (hereinafter: the Directive of 2013), which specifies that issues from the scope of the Directive and their harmonization are of crucial interest to shareholders, members of companies and other third parties. ${ }^{3}$ Thus, in addition to protecting the interests of inves-

\footnotetext{
1 Enron was the seventh largest company in the US economy, employing about 21,000 workers and disposing of assets of more than 66 billion dollars, having achieved total revenue of 100 billion dollars in 2000. After the release of the affair, the value of the company's shares dropped from 90 dollars to 0.80 cents. The value of Enron at the time of the declaration of bankruptcy, on 2 December 2001, amounted to 63,392 billion dollars. Lawrence, A., The Collapse of Enron, McGraw-Hill/Irwin, 2003.

2 Report of the High Level Group of Company Law Experts on a Modern Regulatory Framework for Company Law in Europe. Brussels, 2002. http://www.ecgi.org/publications/documents/report_en.pdf. Last accessed on 07/05/2017.

3 Directive 2013/34/EU of the European Parliament and of the Council of 26 June 2013 on the annual financial statements, consolidated financial statements and related reports of certain types of undertakings, amending Directive 2006/43/EC of the European Parliament and of the Council and repealing Council Directives 78/660/EEC and 83/349/EEC. http://eur-lex.europa. eu/legal-content/EN/TXT/?uri=CELEX\%3A32013L0034. Last accessed on 07/05/2017.
} 
tors in securities, the EU accounting law aims to protect the interests of other parties - creditors, employees and so on. ${ }^{4}$

In the process of negotiations on Montenegro's accession to the EU, accounting and auditing is included in the negotiation Chapter 6. In addition to the rights of companies, this Chapter encompasses part of financial market regulation (regulation of markets of securities, banks, investment funds). ${ }^{5}$ Based on the screening of Montenegrin legislation on companies, upon the recommendation of the European Commission, the Council of the European Union has adopted a Common Negotiating Position for Chapter 6, which lists four benchmark criteria that Montenegro must meet to temporarily close the negotiations in this Chapter. The fourth benchmark relates to the area of accounting and auditing, and includes the obligation of full harmonization of Montenegrin legislation in the area of corporate accounting and auditing with the European Union law and the establishment of an independent and adequately funded authority for public supervision and quality assurance for mandatory (statutory) external audit of the companies.

With a view to meeting the obligations under the accession negotiations, on 30 July 2016, the Parliament of Montenegro adopted the new Law on Accounting (Official Gazette of Montenegro 52/16), while the Proposal for the Law on Auditing was withdrawn from the parliamentary procedure. Adoption of the Law on Accounting and of the Proposal for the Law on Auditing was preceded by a long process of public discussion, carefully followed by the professional community. Finally, the Law on Auditing was adopted on 29 December 2016 (Official Gazette of Montenegro 001/17). In this way, formally and legally, a new phase has begun in the development of accounting and auditing legislation in Montenegro. Namely, in the period from 2005 to the adoption of the Law on Accounting in 2016, accounting and auditing matters were regulated by a single law which was amended several times with different objectives. During the drafting of the laws, under the public discussion and during the consideration of the proposals in the parliamentary committees, long-time problems accompanying these professions have come to the fore. Different views of a part of the professional public on many issues and the need to resolve long-standing

\footnotetext{
4 Henri, O., Pascal, F., Corporate sector accounting and auditing in the EU acquis communitaire, World Bank Group, 2016. http://documents.worldbank.org/curated/ en/387381467995626653/ Corporate-sector-accounting-and-auditing-in-the-EU-acquis-communautaire. Last accessed on 07/05/2017.

5 Jocović, M., Pavlović S., Kompanijsko pravo kroz prizmu pristupanja Crne Gore Evropskoj uniji, Congress of Accountants and Auditors - Collection of Papers: "Perspektive računovodstveno - finansijske profesije u procesu pridruživanja EU", Institute of Certified Accountants of Montenegro, 2013, pp. 247-258.
} 
problems in a quality manner and in accordance with the European Union law and achieved professional international standards make this area a popular research topic. Croatia and Slovenia as neighbouring countries have had similar experience in the process of accession to the EU. ${ }^{6}$

\section{SOURCES OF LAW IN THE EU}

Until 2013, in the context of the development of company law of the European Union, the issues of accounting and auditing were regulated by three Directives - the Fourth, Seventh and Eighth Company Law Directive. The Fourth Company Law Directive (78/660/EEC) was adopted on 25 December 1978, in order to specify the form, content and criteria for the balance sheet and income statement and notes to the balance. In accordance with the above political initiatives, the rules of this Directive were changed in 1990, 2001, 2003, and 2006. The Seventh EU Directive (83/349/EEC) was adopted on 13 June 1983, with the aim to standardize the consolidation of the financial statements in the Member States. This Directive regulated conditions for the preparation of the consolidated balance sheet, methods of compiling the consolidated balance sheet, consolidated statement of operations, consolidated report audit, as well as the publication of consolidated reports. With the entry into force of the Directive of 2013, the Fourth and Seventh Company Law Directives have ceased to apply. The adoption of this Directive and the integration of the previously complex accounting law into one Directive is the result of a broader initiative launched within the EU. Finally, the Eighth Directive regulates the status of persons authorized to audit accounting documents.

Due to their importance, but also the obligation to provide for harmonization in the negotiation process, the text below provides an overview of the basic changes in the Eighth Directive and the Directive of 2013.

The Eighth Company Law Directive. The Eighth Company Law Directive of 2006 establishes rules concerning the statutory audit of annual and consolidated accounts. $^{7}$ The main objective of this Directive is to achieve an EU-wide harmonisation of statutory audit requirements. ${ }^{8}$ The practice of application of the Eighth Company Law Directive of 1984 revealed certain deficiencies, pri-

\footnotetext{
6 For more details, please see: Jankovič, S., et al., Harmonization Of Audit Regulation In The European Union - A Case Of Croatia And Slovenia, Analele Stiintifice ale Universitatii "Alexandru Ioan Cuza" din Iasi, vol. 57, 2010, pp. 3-14. http://anale.feaa.uaic.ro/anale/resurse/ ctbljerman.pdf. Last accessed on 07/05/2017.

7 Article 1, Directive 2006/43/EC.

8 Item 5, preamble to Directive 2006/43/EC.
} 
marily in the area of operation and control. In this regard, in 2004 the European Commission proposed amendments to the Eighth Directive, which have focused on the following important issues: 1) the question of qualification of auditors; 2) audit standards and control - by the provision of the quality control; 3) investigating and sanctioning behaviour that does not comply with the regulatory framework; 4) the public oversight of the audit profession (Chapter 9); 5) the issue of mandatory registration of audit firms in a separate public service; 6) reference to the IFAC audit standards; 7) regulation of the capital structure of audit firms (Chapter 2). ${ }^{9}$ The main provisions of this Directive which we think require a more detailed analysis are related to the following issues:

1. Engaging in the auditing activity. One of the first issues regulated in this Directive, which is regulated in different ways in the Member States, and in particular in candidate countries', including Montenegro, is the issue of approval for engaging in the auditing activity. The Directive stipulates that the statutory audit shall be performed exclusively by statutory auditors or audit firms which are approved by the Member State requiring the statutory audit. However, the above approval is not discretionary - the conditions stipulated by the Directive must be met as regards the educational and professional qualifications, taking the professional exam and examination methods, provision of criteria for withdrawal of approvals, etc. ${ }^{10}$

2. Introduction of an obligation to register auditors and audit firms. The Eighth Directive provides for the obligation of the Member States to keep separate (public) registers of auditors and audit firms. Registration information shall be stored in the register in electronic form and shall be electronically accessible to the public. ${ }^{11}$

3. Strengthening the professional ethics of the audit profession. Changes in the Eighth Directive have paid particular attention (Chapter IV) to the matters of professional ethics, independence, objectivity, confidentiality and professional secrecy. The provisions of this Chapter of the Directive are in many segments comparable to the IFAC Code of Ethics for Professional Accountants, but complete agreement between these documents has not been achieved.

\footnotetext{
9 Kondić, N., Vranješ, S., Revizija u svijetlu propisa Evropske unije, Congress of Accountants and Auditors - Collection of Papers: "Perspektive računovodstveno - finansijske profesije u procesu pridruživanja EU", Institute of Certified Accountants of Montenegro, 2013, pp. 303-312.

10 Articles 3-14, Directive 2006/43/EC.

11 Article 15, Directive 2006/43/EC.
} 
4. The content of the audit report and auditing standards. The Eighth Directive has introduced the obligation on the Member States to require the application of international auditing standards adopted by the European Commission. In this way, the process of standardization is introduced to the sector at the level of the EU and individual Member States. In terms of audit reports, the Directive provides that the audit report shall be signed by at least the statutory auditor(s) carrying out the statutory audit on behalf of the audit firm. ${ }^{12}$

5. The system of public oversight. The Directive has also introduced the obligation for Member States to establish an effective system of public oversight for statutory auditors and audit firms based on the following principles: mandatory nature (all statutory auditors shall be subject to public oversight); impartiality and competence ( the system of public oversight shall be governed by non-practitioners who are knowledgeable in the areas relevant to statutory audit); existence of investigative powers and action-taking; transparency; financial independence (the system of public oversight shall be adequately funded and must be free from any undue influence by statutory auditors or audit firms). ${ }^{13}$

Directive on the annual financial statements consolidated financial statements and related reports of certain types of undertakings. With the entry into force of this Directive, earlier Directives (Fourth and Seventh) have ceased to apply, and Member States were given a transitional period to comply with the contents of the new Directive. The most important requirements of the new Directive relate to the following issues.

1. Classification of legal entities - categories of undertakings and groups. Among the most important changes in relation to the previous accounting law of the EU is the criterion of classification of undertakings. This classification is important because of the manner and scope of reporting, i.e. for compilation and publication of accounting reports and their audit. The goal of the creators of the new solutions was to introduce new objective evidence of the size of the undertaking. The first type of differentiation is the classification of undertakings into micro, small, medium-sized and large. Namely, the preamble to the Directive clearly stipulates that small, medium-sized and large undertakings should be defined and distinguished by reference to balance sheet total, net turnover and the average number of employees during the financial year. ${ }^{14}$ In this regard, new criteria and categories of un-

Articles 26 and 28, Directive 2006/43/EC.

Article 32, Directive 2006/43/EC.

Please see: Item (12), preamble to Directive 2013/34/EU. 
dertakings have been introduced: micro (up to 10 employees, balance sheet total up to EUR 350000 and net turnover up to EUR 700 000); small (up to 50 employees, balance sheet total up to EUR 4000000 and net turnover up to EUR 8000 000); medium-sized (up to 250 employees, balance sheet total up to EUR 20000000 and net turnover up to EUR 40000 000) and large (number of employees above 250, balance sheet total above EUR 20 000000 and net turnover above EUR 40000 000).

The Fourth Directive allowed the possibility for Member States to freely determine the size of the undertakings and the groups, while the new Directive abolished this option. The Member States now have the power to determine the size of undertakings and groups within the prescribed criteria. The most important result of this solution will be the comparability of undertakings and groups within the EU. ${ }^{15}$

2. Notes to the financial statements. The Directive provides that notes to the financial statements shall be presented in the order in which items are presented in the balance sheet and in the profit and loss account. ${ }^{16}$ Also, a set of documents and information is defined that must be contained in them - accounting policies adopted, the total amount of any financial commitments, advances and credits granted to members of the administrative, managerial and supervisory bodies, etc. ${ }^{17}$

3. Obligation to compose a management report and a corporate governance statement. The Directive clearly stipulates an obligation to compose a management report and a corporate governance statement. The Directive provides that management report shall include a fair review of the development and performance of the undertaking's business and of its position, together with a description of the principal risks and uncertainties that it faces. ${ }^{18}$

4. Consolidated financial statements. The Directive has imposed an obligation on the Member States to require any undertaking governed by its national law to draw up consolidated financial statements and a consolidated management report if that undertaking (a parent undertaking) meets the criteria provided in the Directive. ${ }^{19}$

\footnotetext{
Odar, M., Nova računovodstvena Direktiva, Računovodstvo i revizija, No. 9-10, 2013, pp.

16 Please see Article 15, Directive 2013/34/EU.

17 Please see: Article 16, Directive 2013/34/EU.

18 Please see: Article 19, para. 1, Directive 2013/34/EU.

19 Please see: Article 22, Directive 2013/34/EU.
} 4-17. 
5. Publication of accounting statements. Finding a mechanism for efficient publication of information on operations of undertakings presented a significant problem in the company law of the European Union in the past decades. Within this Directive, there is a separate Chapter (Chapter 7) dedicated to the issue of publication of accounting statements. Member States shall ensure that undertakings publish within a reasonable period of time, which shall not exceed 12 months after the balance sheet date, the duly approved annual financial statements and the management report, together with the opinion submitted by the statutory auditor or audit firm..$^{20} \mathrm{Howev}$ er, in the next paragraph of the same Article, the Directive provides for the possibility to exempt undertakings from the obligation to publish the management report where a copy of all or part of any such report can be easily obtained upon request at a price not exceeding its administrative cost.

6. Auditing. Regardless of the fact that auditing is regulated by Directive 2006/43/EC, certain issues are regulated by separate Chapter (VII) of this Directive as well. Firstly, the Directive provides that the financial statements of public-interest entities, medium-sized and large undertakings are audited by one or more statutory auditors or audit firms. ${ }^{21}$ Secondly, the Accounting Directive partly replaces the Auditing Directive (2006/43/EC) in the part related to the auditor's report in terms of introducing new elements it must contain. This is an unusual case of replacement of provisions of a Decree regulating the entire area. ${ }^{22}$ Thirdly, an obligation is imposed on the statutory auditor to express an opinion on whether the management report is consistent with the financial statements whether the management report has been prepared in accordance with the applicable legal requirements. ${ }^{23}$

\section{Responsibility for the financial statements and management reports.}

The Directive introduces the obligation of Member States to provide within their national legislation that the members of the administrative, managerial or supervisory bodies of undertakings are collectively responsible to make sure that the individual and consolidated accounting statements and management reports are prepared and published in accordance with the requirements of the Directive, and if necessary with IAS.

\footnotetext{
Please see: Article 30, Directive 2013/34/EU.

Please see: Article 34, Directive 2013/34/EU.

Please see: Article 35, Directive 2013/34/EU.

Please see: Article 34, para. 2, Directive 2013/34/EU.
} 


\section{CORPORATE ACCOUNTING AND AUDITING IN MONTENEGRO}

The changes at the global level, as well as in the EU, have not bypassed Montenegro. Since the start of self-regulation in this area in Montenegro, a number of regulatory amendments have taken place whose common goal was the introduction of legal security and certainty in this area. We should particularly emphasize the fact that Montenegro has assumed the obligation to prepare financial statements in accordance with the Financial Reporting Framework and International Accounting Standards for Financial Reporting. In theory it is emphasized that one of the benefits of harmonization in the field of accounting law is that it leads to the standardization of rules. ${ }^{24}$ However, in part of accounting profession, in addition to positive effects, this fact has caused an increase in regulation, creating the impression of excessive regulation, whose main consequence is a problem of quality application of the law and creating objective risk of losing the trust of users of financial statements.

Regardless of the improvements in the legal framework, the practice of functioning of these professions in Montenegro is followed by numerous problems. One of the most important problems, which generates a series of open questions, is the existence of two professional organizations dealing with education and issuing relevant certificates. These are: the Institute of Certified Accountants of Montenegro and the Institute for Accounting and Auditing. By 2006, there was one professional organization which dealt with the issues of improving the accounting and auditing profession in Montenegro. Today, the existence of two professional organizations dealing with education and certification and the problems in regulating their status and relationship with the relevant ministry present the cause of deterioration of the quality of personnel in these professions.

\subsection{SOURCES OF LAW IN MONTENEGRO}

The area of accounting and auditing in Montenegro is regulated by a series of legal regulations. The main source of law in this area from 2005 to recent changes of 2016 was the Law on Accounting and Auditing of 2005 (Official Gazette of Montenegro 69/05, 80/08 and 32/11). However, in addition to this Law, the area is also directly or indirectly regulated by the following regulations: Law on Companies (Official Gazette of Montenegro 06/02, 17/07, 80/08,

24 Jevremović Petrović, T., Uvod u kompanijsko pravo EU, in: Vasiljević, M., et al. (ed.) "Kompanijsko pravo Evropske unije", Faculty of Law, University of Belgrade, Belgrade, 2012, p. 38 . 
40/10 and 36/11); Law on Securities (Official Gazette of Montenegro 59/00 and 40/11). Furthermore, in addition to the laws, this matter is regulated by the following by-laws: Decree on entrusting the affairs of the public administration responsible for the accounting and auditing (Official Gazette of Montenegro 44/07), Rulebook on the forms and content of forms for the financial statements of companies and other legal entities (Official Gazette of Montenegro 33/10 and 44/07) and the Rulebook on the financial statements of investment funds (Official Gazette of Montenegro 32/12).

The described changes, which have since taken place primarily at the level of the EU, led to the amendments to the Law on Accounting and Auditing in 2008. Seen from today's perspective, while keeping in mind the conditions prevailing in Montenegro at that time, we can express the view that these amendments have brought a number of improvements in the regulation of accounting and auditing profession. The most significant novelties compared to the previous law were the following:

- Criteria were prescribed for the classification of legal entities;

- An obligation was introduced to submit quarterly and annual reports, as well as consolidated financial reports in both, hard-copy and electronic version;

- The list of persons responsible for published financial reports of general purpose was extended;

- The deadline for submission of financial statements was changed;

- The criteria were changed for performing audits;

- Questions related to the issuance of licences to auditors, conduct of the audit, contents of the auditor's opinion, obtaining and withdrawing the licence for work and so on were regulated in more detail;

- The Council for Accounting and Auditing was introduced.

After reviewing the positive law by 2016, while taking into account the overview of the relevant Directives, the following areas may be listed as the main areas of non-compliance with EU law: 1) deficiencies in the area of financial reporting; 2) the lack of public oversight of auditors and audit firms; 3) defining the thresholds for classification of legal persons and mandatory audits for medium-sized legal entities; 4) incompliance with the preparation of the annual and consolidated management report; 5) questions of professional ethics, independence, objectivity, confidentiality and keeping professional secrets (complying with the Eighth Directive). 


\subsection{THE NEW LAW ON ACCOUNTING}

On 12 October 2014, the Government of Montenegro launched a public discussion on the Draft Law on Accounting, which lasted until 30 November 2014. The Proposal for the Law was submitted to the parliamentary procedure on 22 June 2016. One of the main reasons was the harmonization of accounting activity to changes within the EU arising from the adoption of Directive of 2013. In addition to this objective, the new Law was an attempt to improve the existing legislation in this area and to bring it closer to the practical demands, overcome the observed long-standing problems, make the financial reporting system more transparent and ensure better control of the financial statements in accordance with international best practice. This Law regulates: the classification of legal entities, conditions and manner of bookkeeping, accounting organization, preparation, submission and publication of financial statements, conditions and manner of carrying out the valuation of assets and other issues of importance for accounting, evaluation and financial reporting. Below we will give an overview of the most important solutions in the new text of the Law:

1. Harmonization with the rules of the Directive relating to the classification of legal entities. In accordance with the rules of the Directive, the Law on Accounting introduces an obligation of the classification of legal entities to micro, small, medium-sized and large, depending on the balance sheet total, net annual turnover and the average number of employees. It is especially important to emphasize that this classification is done solely for the purposes of taking over the rights and obligations under this Law, and that it does not affect the other regulations of company law. Comparative experience shows that it is possible to have different categorizations of legal entities in different areas.

2. Harmonization with the Directive in respect of the consolidated financial statements. The Law provides that the parent legal entity is obliged to prepare, submit and publish consolidated financial statements in accordance with the law, International Accounting Standards and International Financial Reporting Standards. Also, in accordance with the Directive, the Law foresees the detailed rules regarding the exemption from the consolidation of financial statements.

3. Preparation and submission of financial statements. The Law places a special focus on this issue, important not only from the perspective of accounting, but also from the need to enhance the transparency of operations of legal entities as one of the essential foundations of functioning of company law. In addition to the obligation to prepare annual financial statements and consolidated statements as at 31 December of the business year, the 
same obligation exists for legal entities at the date of registration of status changes (merger, acquisition, division), as well as on the day of rendering the decision on voluntary liquidation of the legal entity.

4. The obligation to prepare annual and consolidated management reports. The obligation to prepare these reports should, primarily because of their content, significantly improve the system of corporate governance in the future. The Law imposes the obligation to prepare such reports on large legal entities, medium-sized legal entities and legal entities issuing securities and other financial instruments traded on a regulated market.

5. Entities of public interest and a declaration of implementation of Corporate Governance Code. One of the novelties of this Law is the introduction of the institute of entities of public interest in the company law of Montenegro. Under this Law, the entities of public interest are: legal entities issuing securities and other financial instruments traded on a regulated market; banks and other financial institutions; insurance companies; legal entities classified in the category of large legal entities in accordance with the Law. For entities of public interest, the Law provides for an obligation to submit, along with the annual financial statement, the declaration of implementation of Corporate Governance Code; information about significant direct and indirect shareholders of the legal entity, as well as data on the composition and work of the executive, management and supervisory bodies and their committees.

6. Responsibility for the preparation and publication of financial statements and management reports. In relation to this sensitive and so far insufficiently harmonized solution, the new Law has been harmonized with EU law. Namely, the collective responsibility of members of management and supervisory bodies for the preparation and publication of financial statements and management reports has been introduced. In addition to the compliance with EU law, the above solution should be a step towards the gradual maturing of the awareness of the importance of the introduction of professional structures in the composition of management and supervisory bodies in companies in Montenegro.

7. Business books and certification of accountants. A separate part of the Law deals with the matter of bookkeeping and certification of accountants. During the public discussion, a very sensitive issue was the regulation of the matter of certification of accountants. The Law foresees four conditions for obtaining the title of certified accountant: 1) passing the exams established by the programme of the relevant Ministry or a legal entity entrusted with carrying out such tasks in accordance with the IFAC training standards; 2) VII-1 level of education; 3) three years of work experience in accounting. 


\subsection{THE NEW LAW ON AUDITING}

On 21 October 2014, the Ministry of Finance launched a public debate on the Draft Law on Auditing, which lasted until 30 November 2014. At its session of 31 March 2016, the Government of Montenegro adopted the Proposal for the Law and submitted it to the parliamentary procedure. However, unlike the Law on Accounting, this Law was not adopted at the session of the Parliament in July 2016, but in late 2016. Preparation of the Law on Auditing and its compliance with EU law is an obligation of Montenegro arising from the accession negotiations. However, in addition to compliance with changes in the company law in this area, the aim of its adoption is also to promote the work of the auditing profession. The following text provides an overview of the most important solutions of the Law on Auditing:

1. Auditing standards. In accordance with the solutions set out in EU law and comparative law worldwide, Montenegro has adopted a decision by which audits are conducted in accordance with International Standards on Auditing (ISA), promulgated by the International Auditing and Assurance Standards Board (IAASB), as a body of the International Federation of Accountants (IFAC).

2. The conditions and manner of conducting the audit. One of the most important issues in practice, which has received considerable attention in the recent period in EU law, is defining the necessary conditions for conducting the audit. The Law regulates this area by separately prescribing the following questions: 1) the status of certified auditor; 2) professional ethics, independence and objectivity; 3) the conflict of interest of auditors; 4) the question of issuance, recognition and revocation of license for auditors; 5) continuous professional education; 6) the legal status of the auditing firm, obtaining and revocation of licenses for carrying out activities; 7) liability insurance for auditors. During the public discussion, special attention was focused on the issues of the legal status of the auditing firm and the status of certified auditor.

3. Audit reports and transparency. A separate part of the Law governs a series of questions relating to the audit report and its contents. Also, the obligation to prepare a transparency report is introduced. Specifically, Article 26 of the Law provides that the auditing firm or certified auditor shall, by 31 March of the current year, submit to the Audit Council the transparency report for the previous year, for the purpose of publication on the website of the Audit Council.

4. Mandatory nature of audit and internal audit. The Law significantly expanded the circle of legal entities for which audit is mandatory. According 
to the proposed solution, these entities are: 1) the entities of public interest; 2) medium-sized legal entities; 3) parent legal entities meeting the requirements for classification in the group of medium-sized legal entities together with their subsidiaries; 4) parent legal entities, meeting the requirements for classification in the group of large legal entities together with their subsidiaries; 5) investment companies; 6) investment funds; 7) companies for managing investment funds; 8) voluntary pension funds; 9) companies for managing voluntary investment funds and 10) other collective investment schemes. The Law introduces the obligation for large legal entities to have an internal auditor.

\section{Regulation of the issue of supervision of work of auditing firms.}

6. Audit Council - a body for monitoring the improvement of auditing practices. An affirmative solution of the Law on Audit is also the introduction of a special body - the Audit Council, which is mandated to monitor and improve auditing practices. During the public discussion, the issue at dispute was the representation of the profession in the membership of this body and the nomination of its members - should all the members be nominated by the Minister of Finance (the proposed solution) or should professional organizations be allowed to nominate candidates for membership? At the end, the accepted solution is that the Audit Council shall have five members that are appointed and dismissed by the Government, at the proposal of the Minister of Finance.

7. Audit Committee. The legal entities, for which audit is mandatory, must also have an Audit Committee. The Law thoroughly regulates the structure, number of members, manner of appointment, and the competences of the Audit Committee. Regardless of the fact that the activity of this Committee is directly related to the field of audit, certain questions regarding the Committee should have been regulated by the Law on Companies. In this way, there may be an overlap between the two Laws, because the formation of the Audit Committee for public joint stock companies is one of the recommendations of the European Commission in the area of improving company law and corporate governance, so it is logical for it to be incorporated in the text of the Law on Companies. In the public discussion, the proposal in this area was that at least one member of the Audit Committee must be a professional in the field of accounting and auditing, having the certified accountant status. However, in the explanation of the text of the law, this proposal was not accepted with the argument that such an Article would not be in compliance with Directive 2006/123/EC on services in the internal market. 


\section{CONCLUSION}

After the analysis of the changes in the regulatory framework in the field of accounting and auditing in Montenegro from 2005 until today, the conclusion is that the legal framework has been substantially brought in compliance with EU law and the international standards. Amendments to the former Law on Accounting and Auditing, and in particular the adoption of the new Law on Accounting, as well as the existing Proposal for the Law on Auditing, gradually led to achieving the international standards in this area.

However, in the legal analysis of this area we should not ignore the main purpose of passing laws (which is often the case in the process of accession to the EU!). Namely, achieving compliance with EU law is not a goal in itself. In the field of company law (Chapter 6), the harmonization process should contribute to strengthening the competitiveness of the national economy and improving the quality of law in this area. After analyzing the process of adoption and implementation of the above laws, an additional conclusion has arisen - that in the process of adopting the Law on Accounting and the Law on Auditing, the legislator placed greater emphasis on formal alignment with EU law than on the need for laws to create prerequisites for further development of these areas in Montenegro. In a significant number of cases, the arguments of the professional public, which was interested in the adoption and will be responsible for the implementation of these Laws, was not accepted, being refused with often short and insufficiently substantiated explanation of non-compliance with the EU acquis. Despite the high transparency in the law-adoption process, more understanding was missing to consider the practical needs and find a balance between the requirements of EU law and the need for further development of accounting and auditing in Montenegro.

Compliance with EU directives in this area and systematic and transparent nature of legal texts may be listed as affirmative conclusions after analysis of those Laws. However, certain issues, because of their topical character, may cause problems in the application and interpretation of the Laws in the coming period. Also, the failure to adopt certain solutions that were proposed during the public discussion may result in a drop in the quality of these two professions. At the end of the analysis, the most important observations are provided.

In terms of the adopted Law on Accounting, the potential problems could be the following: bookkeeping and signing of financial statements; non-introduction of certificates from the Montenegrin educational accounting standards for the signatories of financial statements or the introduction of a new programme for the signatories of financial statements; non-introduction of a single register of providers of accounting services; failing to tackle the possibility of consol- 
idation of the institutes providing education in this area. In the course of the public discussion, some of these issues were initiated by professional associations, but were not accepted with an explanation of their non-compliance with EU directives. One of the most contentious issues in the process of adoption of this Law was bookkeeping or more specifically the failure to adopt provisions that only professionals (certified) can keep business books. In the Law on Accounting, a liberal solution was adopted, according to which any person who has not been convicted of criminal offences that make him unworthy to perform activities in the field of accounting can keep business books and prepare financial statements. Thus, stricter criteria to protect the profession, improve the quality of the profession and protect the interests of other holders of interest in relation to companies are missing. In any case, by using this solution, the legislator has taken responsibility for possible long-term consequences that can be caused by the fact that under-qualified or unqualified persons without the necessary knowledge are carrying out this serious and responsible role in the companies.

In relation to the Law on Auditing, the potential problems indicated during the public discussion related to the following issues: the question of membership in the Council for Public Oversight of Auditors (greater representation of the profession); introduction of obligation to conclude an employment contract for the audit firms with at least one auditor. Although some of the above proposals were rejected with the argument of non-compliance with the principle of freedom to provide services in the EU and the relevant directives regulating this area, taking into account the achieved level of integration of Montenegro and the need to protect the existing companies in this area, it can be concluded that there was room for the Law to incorporate certain solutions that would protect the profession (e.g. membership in the Audit Committee and the Audit Council, the introduction of obligation to conclude an employment contract for the audit firms with at least one auditor) and enable its development and competitiveness at least until the date of entry Montenegro to the EU.

\section{LITERATURE:}

1. Jankovič, S., et al., Harmonization Of Audit Regulation In The European Union A Case Of Croatia And Slovenia, Analele Stiintifice ale Universitatii "Alexandru Ioan Cuza" din Iasi, vol. 57, 2010, pp. 3-14.

2. Jevremović Petrović, T., Uvod u kompanijsko pravo EU, in: Vasiljević, M., et al. (ed.) "Kompanijsko pravo Evropske unije", Faculty of Law, University of Belgrade, Belgrade, 2012.

3. Lawrence, A., The Collapse of Enron, Mcgraw-Hill/Irwin, 2003. 
4. Henri, O., Pascal, F., Corporate sector accounting and auditing in the EU acquis communitaire, World Bank Group, 2016.

5. Jocović, M., Pavlović S., Kompanijsko pravo kroz prizmu pristupanja Crne Gore Evropskoj uniji, Congress of Accountants and Auditors - Collection of Papers: "Perspektive računovodstveno - finansijske profesije u procesu pridruživanja EU", Institute of Certified Accountants of Montenegro, 2013.

6. Kondić, N., Vranješ, S., Revizija u svijetlu propisa Evropske unije, Congress of Accountants and Auditors - Collection of Papers: "Perspektive računovodstveno - finansijske profesije u procesu pridruživanja EU", Institute of Certified Accountants of Montenegro, 2013, pp. 303-312.

7. Report of the High Level Group of Company Law Experts on a Modern Regulatory Framework for Company Law in Europe. Brussels, 2002.

8. Directive 2006/43/EC of the European Parliament and of the Council of 17 May 2006 on statutory audits of annual accounts and consolidated accounts, amending Council Directives 78/660/EEC and 83/349/EEC and repealing Council Directive 84/253/EEC.

9. Directive 2013/34/EU of the European Parliament and of the Council of 26 June 2013 on the annual financial statements, consolidated financial statements and related reports of certain types of undertakings, amending Directive 2006/43/EC of the European Parliament and of the Council and repealing Council Directives 78/660/EEC and 83/349/EEC..

10. Law on Auditing, Official Gazette of Montenegro, 001/17.

11. Law on Accounting, Official Gazette of Montenegro, 52/16. 
